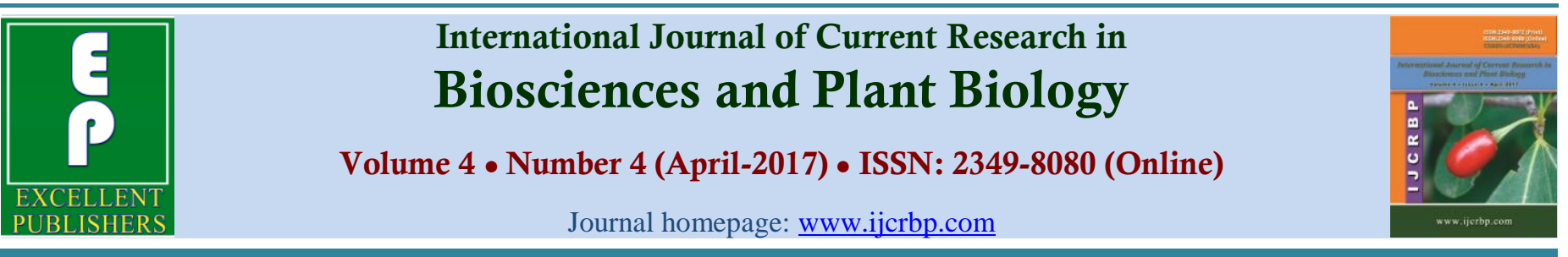

\title{
Two New Species of Loxogramme and Lepisorus (Polypodiaceae): Endemic Ferns from Kivu-Ruwenzori Mountain System (Eastern D.R.Congo, Albertine Rift)
}

\author{
Jean De Dieu Mangambu Mokoso ${ }^{1,2} *$ and Ruurd van Diggelen $^{2}$ \\ ${ }^{I}$ Université Officielle de Bukavu, Département de Biologie, Laboratoire de Systématique Végétale et de Biodiversité, Bukavu, \\ D.R. Congo \\ ${ }^{2}$ Department of Biology, Vegetal Ecology Ecosystem Management Research Group, Antwerp University, Antwerp-Wilrijk, Belgium
}

*Corresponding author.

\begin{abstract}
This article mentions the presence of two new species or variation discovered and described once in the Kivu-Ruwenzori mountain system in D. R. Congo. The used methodology is related to taxonomy treatment of herbarium with macroscopic and microscopic observations of spores. We have also established chronological and ecological analysis. Loxogramme ntahobavukiana to simple fronds, pinnately lobed, notched, oblanceolate the base and without sori exindusiate, elongated, oblique to costa. While Lepisorus robbrechtiana was characterized by monomorphic fronds, with a tendency to fronds monomorphic, with a tendency of dimorphism, lamina of two kinds, assimilating holders of sori, long each lobed at the vein rib fork, and others are short integers and simple vein.
\end{abstract}

\section{Article Info}

Accepted: 31 March 2017

Available Online: 06 April 2017

Keywords

Endemic Kivu-Ruwenzori mountain system Lepisorus robbrechtiana Loxogramme ntahobavukiana Polypodiaceae

\section{Introduction}

During our taxonomic research on ferns and allies ferns of the mountains of the eastern Democratic Republic of Congo (DRC), two new species of Polypodiaceae, Loxogramme ntahobavukiana (Subfamily Polypodioideae, tribus Loxogrammeae (Roux, 2001) and Lepisorus robbrechtiana (Subfamily Polypodioideae, Tribus Microsoreae (Roux, 2001) were collected and identified as new. Both species are perennials, hemi-epiphytes of shrubs or trees. The first species was found in the Lemera and Kalehe areas middle plateau, in the Tshivanga mountain area (Kahuzi-Biega National Park "KBNP") and in the Burhinyi escarpments at the
Itombwe Natural Reserve (INR). As for the second species, apart from the specimens collected from the KBNP, its two samples were collected in the volcanic rocks of the Virunga National Park (ViNP) in the vicinity of Kilimanyoka.

The species named Loxogram ntahobavukiana has affinity with Loxogramme abyssinica, which is an East African Afromountain species, and Lepisorus robbrechtiana also has similarities with Lepisorus excavatus, an Afro-Madagascan species. A similar case, the confusion between Lepisorus excavatus, and the new species Lepisorus robbrechtiana, was reported by Mangambu (2013). Several specimens of the KBNP and 
a specimen of the ViNP, belonging to this new species, have also been found in the undetermined material of the genus. The two new species are dedicated to the two professors (Robbrecht and Ntahobavuka) who have carried out several researches in this region of the Congo-Nile Ridge in eastern Congo. This is a way to honor and immortalize them.

The two new species described belong to the family of Polypodiaceae, which are leptosporangiated isospora ferns characterized by Fronds mono-, hemi- or dimorphic, articulated or not; stipe short or long, terete or adaxially shallowly sulcate; lamina simple, unequally lobed or pinnatifid, entire or shallowly crenate; hypostomatic. Sori circular, oval, linear or in a soral patch, superficial or slightly sunken, then embossed, scattered or in a single row on either side of the primary or secondary vein, positioned at the apex of the acroscopic vein branch, at a vein plexus or on a soral vein; sporangium stalk short or long, simple, 3-seriate below the capsule; capsule globose, with 12-21 indurated annulus cells and a well-defined stomium; exindusiate; receptacle nude, with simple pluricellular hairs, stellate hairs or with peltate clathrate paleae. Spores ellipsoidal, monolete or trilete, smooth, granulate, rugate, rugose or tuberculate.

Polypodiaceae has a near cosmopolitan distribution with the greatest diversity in tropical areas, especially in Asia. This order contains species that have relatively young forms in full development and their systematic is not yet definitively established (Autrey et al., 2008; Roux, 2009; Crouch et al., 2011). The number of families and genus are extremely variable. For this paper, we used the classification of Roux (2009).

Indeed, the studies carried out by Fischer (1996) and Mangambu et al. (2014) in KBNP and Plumptre et al. (2007 and 2009) in the mountainous massifs (ViNP, PNKB and INR) of eastern DRC, emphasize that the Montana forests of this Kivu-Ruwenzori system are among the most complex and important ecosystems from the point of view of Floristic richness in ferns and fern allies other vascular plants. For this reason, they are considered to be of great importance for the conservation of endemic and endangered species (Plumptre et al., 2007; Mangambu et al., 2015). They are characterized by an orophilous flora and have exceptional and rich floras, with a singularity which is the high endemism rate, with more or less 3000 endemic species (Plumptre et al., 2007 and 2009).
Recent studies in pteridology (Pichi-Sermolli, 1983 and 1985; Lawalrée, 1990; Roux, 2009; Mangambu et al., 2016) and other works of vascular plants (Fischer et al., 2003; Detchuvi and Fischer, 2006; Cribb et al., 2010; Lachenaud and Jongkind, 2010) showed the description of several new species of the Congo-Nile Ridge where these three conservation domains of the eastern DR Congo are located.

In our collection and study site, apart from the work of Pichi-Sermolli (1983 and 1985) and Lawalrée (1990), apart from some fascicles from Central Africa, the thesis of Mangambu (2013) and the publications of Mangambu et al. (2012 and 2016), there is no work to strengthen the systematic knowledge in deep pteridology. The overall goal of this article is to describe these new species. The specific objective is to indicate their ecological conditions as well as their phytogeographical.

\section{Materials and methods}

\section{Study area}

The Kivu-Ruwenzori mountain system is located in the Albertine Rift and consists of the mountain ranges of which the Mount Mitumba (White, 1978) in the eastern and western ridge of the Kivu (White 1978 and 1993); the contiguous highlands from the northern end of Lake Tanganyika to the Ruwenzori and also the western part of Burundi as well as southeastern Rwanda and Uganda (Roche, 1991; Linder, 2001). They are largely composed of Precambrian rocks but also local islands of volcanic deposits including the Virunga volcanoes $(4507 \mathrm{~m})$ still active (Fig. 1).

Among the mountains constituting this mountain range, some are vestiges of the uprising on the edge of the great African plateau, while others, notably the Ruwenzori (5119 m), have been raised under the forces of compression linked to the formation of Grabens. Others are weakly developed on very steep slopes between 2200 and $3200 \mathrm{~m}$ (Kahuzi-Biega National Park, Mangambu, 2016). The three conservation areas of the eastern DRC, namely the Kahuzi-Biega National Parks (created in 1970), the Virunga National Parks (created in 1925) and the Itombwe Natural Reserve (created in 2006) are found in that system (Plumptre et al., . 2008 and 2009). In Congolese conservation areas, they protect Eastern lowland Gorillas (KBNP and INR) and the Mountain Gorillas (ViNP). 


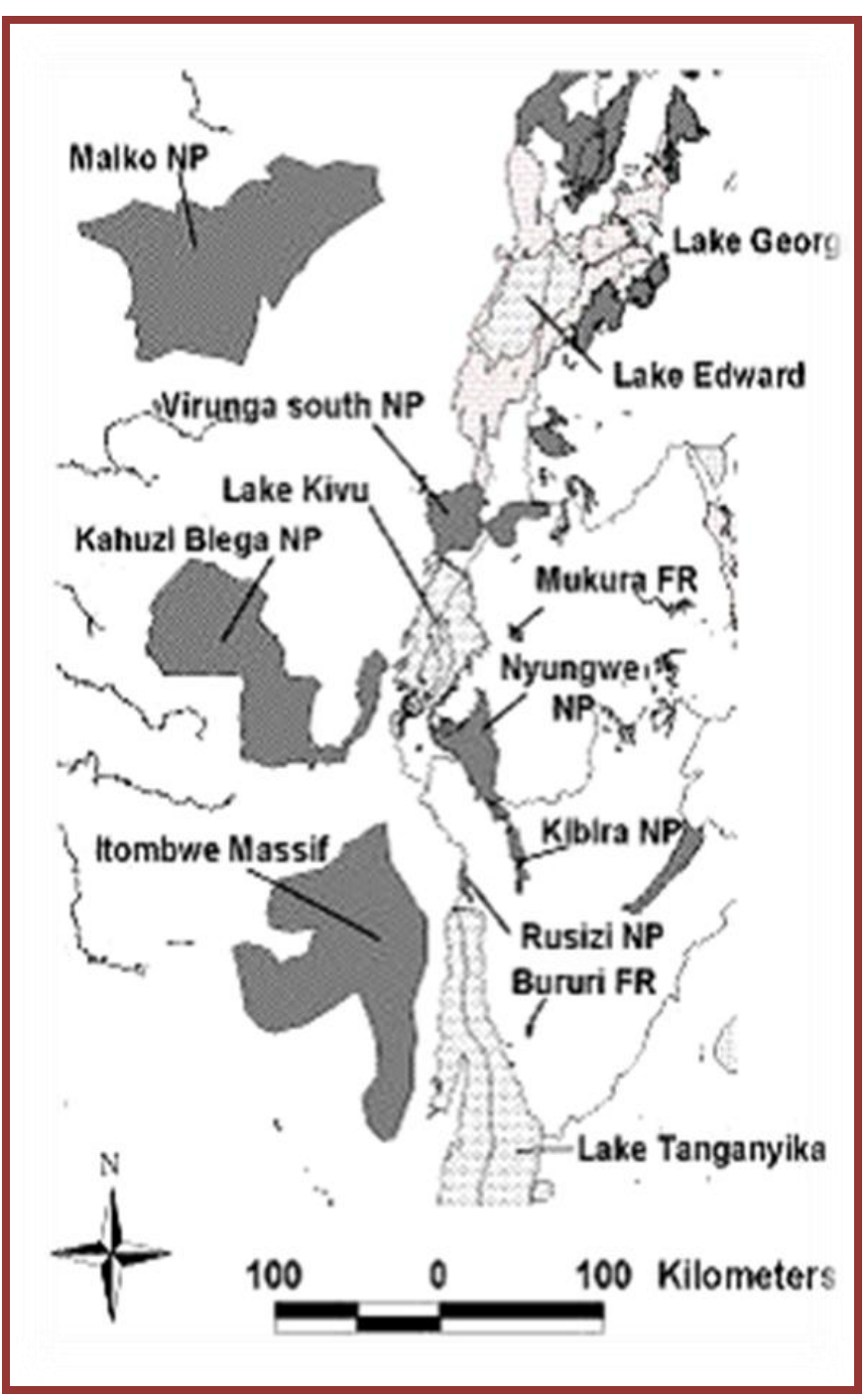

Fig. 1: Map of the Albertine Rift showing existing protected areas or regions referred to in this study and the approximate boundary of the Albertine Rift (portions of the Albertine Rift showing the locations of the various protected areas (NP: National Park; FR: Forest Reserve; WR: Wildlife Reserve). The Latitude and longitude around the map are labeled in degrees.

\section{Collection and identification}

The specimens that we use in this paper were collected mainly between April 2004 and June 2015 in the Kahuzi Biega National Park (PNKB), and also in the two neighboring conservation areas (ViNP and RNI). They were deposited at the Herbarium of Lwiro in the DRC (LWI), with duplicates in the herbarium of the National Botanical Garden of Belgium (BR).In order to identify it and to give distinctive features to species with affinities, we have made macroscopic and microscopic observations of the following characteristics:

- qualitative characteristics (shape of rhizome, presence or absence of scales, color of scales, general habit of stem or stipe, type of fronds and veination, disposition, costa, costules, sori, form of spores);

- quantitative characteristics (height of the plant, size of frond, stipe, pinna, rhachis, ultimate segment, rachis, spore dimension).

\section{Laboratory analyzes}

\section{Spores observation}

For morphological observation of spores, we proceeded in two steps (Hu et al., 2010) to BR:

- The first operation which consists in dissecting sporangia on a slide and under a four-step process. The initial step consisted in placing the spores inside $1.5 \mathrm{ml}$ microtubes with $70 \%$ ethanol. This initial treatment was followed by placing the microtubes inside an ultrasonic wave bath (1510 BRANSON, 50-60Hz, 90W) for $10 \mathrm{~min}$.

- This second step was followed by $4 \mathrm{~min}$. centrifugation $(6000 \mathrm{rpm})$. This three steps protocol was repeated three times, each washing step $(70 \%$ ethanol) required a re-suspension of the pellet of spores. Subsequent to this treatment, the spores and washing $70 \%$ ethanol solution were transferred to a double sided adhesive tape with a micro-pipette. Once the $70 \%$ ethanol solution vaporized the dried spores were gold coated using standard electron microscopy techniques. These samples were subsequently observed and photographed under a Hitachi JSM-6360LV Scanning Electron Microscope.

\section{Encoding, taxonomic, chronological and ecological treatment}

The methodology used is the herbarium taxonomical treatment. Phytochoria of White (1986 and 1993) were followed. The ecological factors, i.e. habitat type, altitude interval for collected specimens and adaptation of the species were recorded in the field. In order to enable encoding, we proceeded with data management and treatment. The herbarium collections were encoded using the BRAHMS $5.65 \circledR$ software. 


\section{Results}

\section{Description of the two new species}

\section{Loxogramme ntahobavukiana Mangambu \& van Diggelen sp. nov.*}

Typus: Mangambu 3711 (BR, LWI): South Kalehe (208501, E2850881) $1612 \mathrm{~m}$ collected on 7july 2011 (holo-, BR!; iso-, LWI!).

Description: Epiphytic, perennial, ascending Plant of small size varying between $36.4-72.2 \mathrm{~cm}$ long, prostrate; Rhizome slender, with masses of hairy roots and greysh clathrate scales, widely creeping, branched, covered with narrow, dense, peeled, foamed scales at the top, pale brown to brown in color, margin with numerous extensions along the whole length and provided with 2 ridge rows of short phyllopods pale or black, lanceolate, acuminates. Fronds in tufts, monomorphic, articulated, up to $16.2-38.22 \mathrm{~cm}$ in length; Stipe 3.78-4.6 cm long, stramineous to purplish, distinct articulation, sometimes distinct in a young, non-functional state; lamina 5-36 x $1-9 \mathrm{~cm}$ long, pinnately lobed, sometimes notched, regularly sinuate, crenelated while still young, glabrous on the upper side, scales on the lower side; veins indistinct, obsolete glabrous on upper surface, midrib and veins immersed; areoles oblique to the main vein; presence of more or less inclined veins; staminated rhachis, elevated on the underside, almost indistinct on the upper surface. Indumentum composed of clavate,2celled hairs occurring abaxially on the lamina and basifixed clathrate paleae ending in a small thin-walled cell, often with shortunicellular trichomes along the proximal margin of the paleae occurring on the rhizome and stipe base. Sori subglobose linear, elongated, 6 to $11.6 \mathrm{~cm}$ long, exindusiate, oblique to the main vein, the top of each sori slightly or does not exceed the base of the upper sori; sporangia usually with cylindrical glands, often deciduous in the adult state, with a thin, short pedicel; Spores oblovoidal, monolete Gametophyte mature thallus ribbon-shaped, often profusely branched, rhizoids mostly in marginal clusters, glabrous, gametangia borne on scattered superficial cushions ventrally behind the meristematic region; archegonium neck with 3 tiers of cells, nearly straight, neck canal cell binucleate; vegetative reproduction by unicellular marginal gemmae (Figs. 2 and 3).

Ecology, habitat and distribution: hemi-epiphytic plant, often lithophyte of very covered environments, or sometimes on spontaneous trees, sometimes at $30 \mathrm{~m}$ above ground in the undergrowth in secondary forests in submontane level. In the montana level, present in the covered and open areas, there are moist forest galleries with Syzygium spp., Symphonia globilifera and / or sometimes in the bottom of the ravines and in the marshes; sometimes also in the dry zone along the ravines. Altitude: 1390-2130 m. Endemic species of Kahuzi-Biega National Park and Itombwe Natural Reserve.

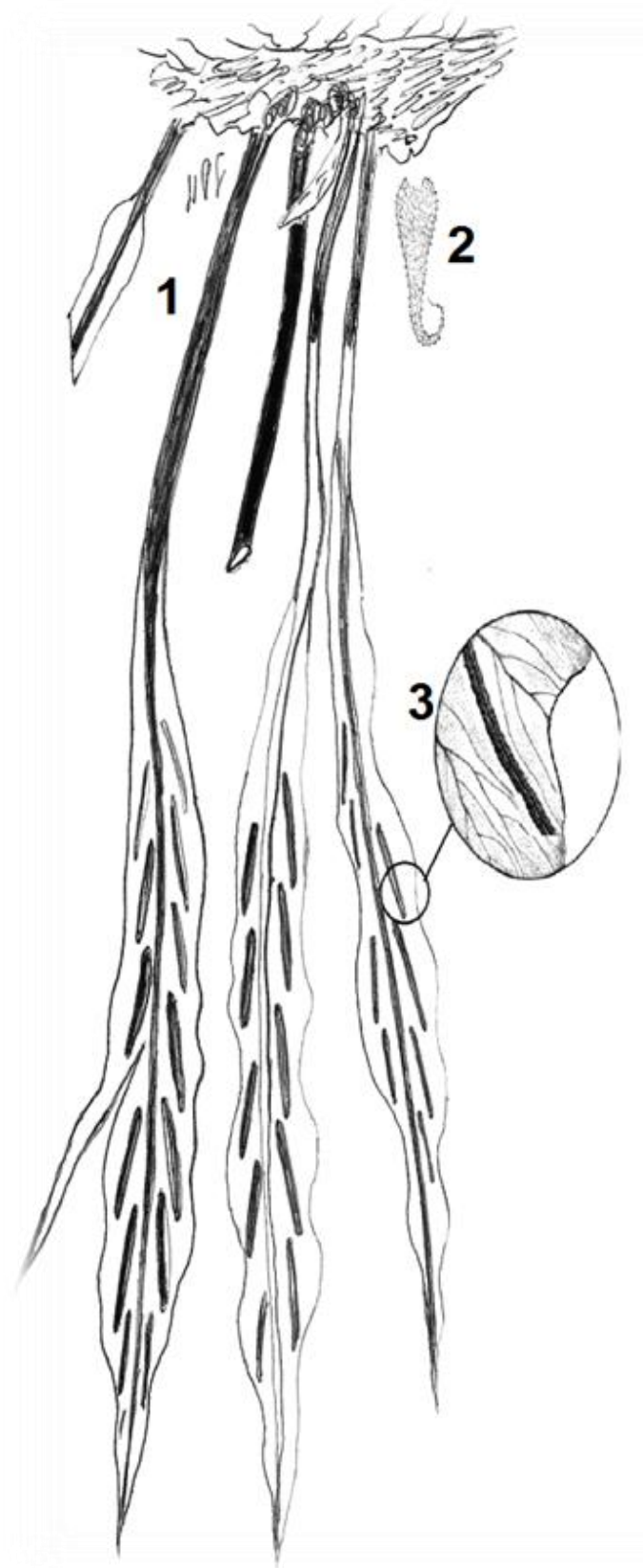

Fig. 2: Loxogramme ntahobavukiana: 1, full plant x1; 2, scalped $\mathrm{x} 1 / 5$ and 3 , lamina portion in sore (x 3 ). 

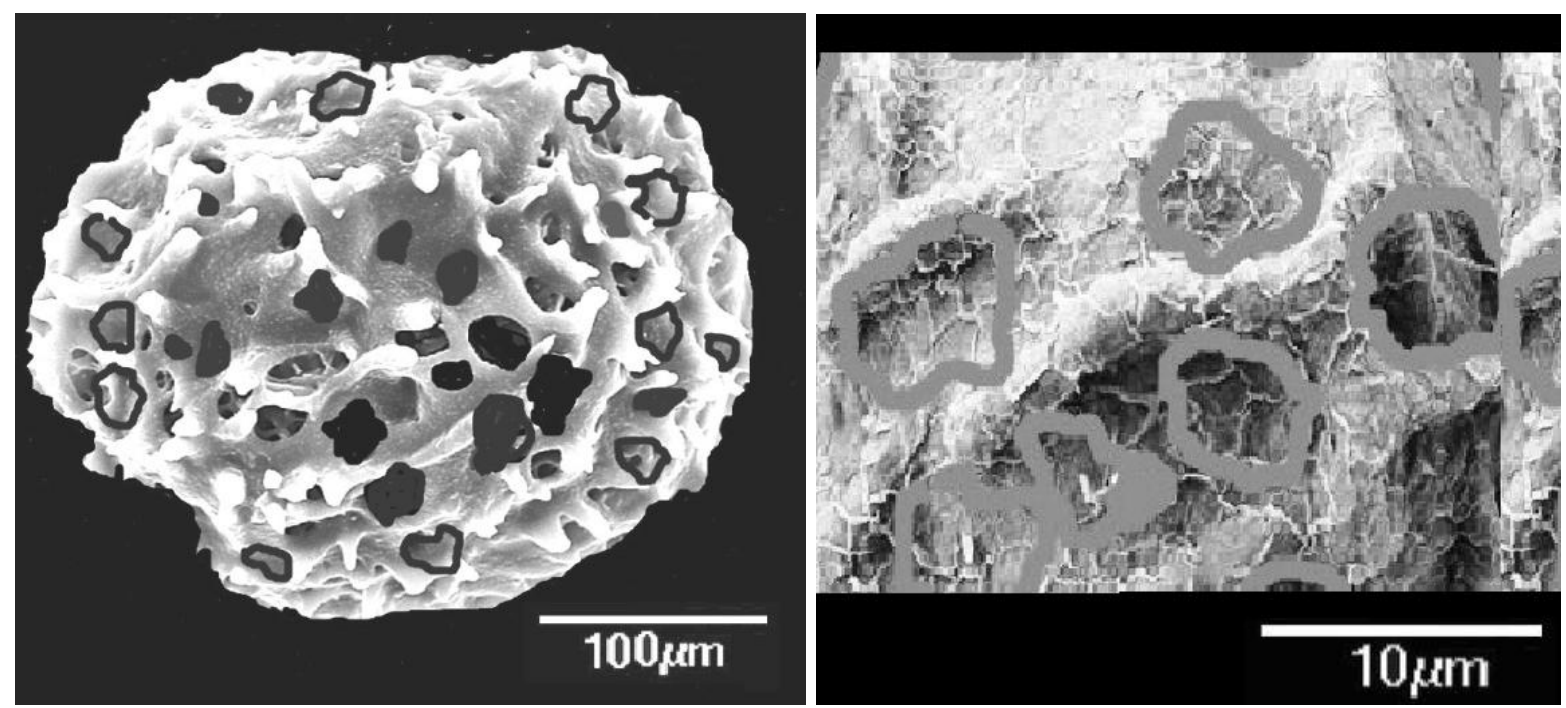

Fig. 3: Loxogramme ntahobavukiana: original images of electronic scanning microscope showing the overall view of mono oblovoidal spore $(100 \mu \mathrm{m})$ and magnification $(10 \mu \mathrm{m})$.

Other specimens examined: Ntamwira 222 (BR, LWI) : Burhinyi (RNI, S309245, E2834265), $1659 \mathrm{~m}$ alt.; Mangambu 3338 (BR, LWI) : Lemera Nord (S203973, E2842950), 1733 m alt.; Mangambu 3355 (BR, LWI) : Northern Lemera (S204.970, E2850.289), $1745 \mathrm{~m}$ alt.; Mangambu3912 (BR, LWI) : Tshivanga (S217178, E2846349)1587 alt.; Mangambu 3827 (BR, LWI) : Tshivanga(S213406, E2848992) $2012 \mathrm{~m}$ alt.;Mangambu 3711 (BR, LWI) : South Kalehe (208501, E2848229) 1612 m alt. ;Mangambu 3827 (BR, LWI) : South Kalehe (208501, E2850881) 1612 m alt. ; Mangambu 3912 (BR, LWI) : SouthKalehe (208501, E2850881) $1612 \mathrm{~m}$ alt. ; Anataka 12 (LWI) : Tshivanga (217178, E 2846349), $2050 \mathrm{~m}$ alt.

Notes: simple Fronds, notched lamina, pinnately lobed, oblanceolated base; sori without indusia, elongated, oblique in relation to the costa. The specimens Mangambu 3338 and Mangambu 3355 except the general characters, their pinna are long lobed.

\section{Lepisorus robbrechtiana Mangambu \& van Diggelen sp. nov.*}

Typus: Mangambu 2922(BR, LWI): Tshibati Nord (S208.997, E2850.616): $1745 \mathrm{~m}$, collected on 22 may 2010 (holo-, BR! ; iso-, LWI!).

Description: Perennial, hemi-epiphytic, ascending plant, $11.7-49.23 \mathrm{~cm}$ of length. Rhizome Creeping, with brown clathrate lanceolate to narrowly ovate-acuminate rhizome-scales up to $5.5-7.1 \mathrm{~cm}$, covered with paperylaced scales, more or less pale, lanceolate, pale margin, subentire to irregular. Fronds nonomorphic, in unequal sizes, some long, others short, tender, spaced, erect; stipe more or less short, hairy, stratified to brownish, $2-10.5 \mathrm{~cm}$ long, $1.2-1.5 \mathrm{~mm}$ in diameter, scaly, gradually narrowed at the base at the base and decurrent over most of the length of stipe in a very fine wing, furnished with scales scattered on the upper surface, more numerous on the inferior side; tiny scales, peeled, appressed, ovatelanceolate, black in center, lacerated; lamina not identical and unequal, one is long and lobed (30.7-41.9 cm) dichotomous at the top (once to twice in forks), the others wholly small $(8.2-16.6 \mathrm{~cm})$; margin reflected a little, sometimes slightly undulating; rachis stramineous, raised on both sides; dichotomous veinat the top (twice to three times following the long lamina), according to the form of a long penne fork, median vein not dichotomous, prominent anastomosing, rounded in the abaxial part, canaliculated in the adaxial part; areolas with several veins included. Indumentum composed of 2-4-celled, clavate hairs, apical cell appears glandular, the stalk simple or with 1 (rarely 2) clavate, glandular trichomes occurring adaxially and/or abaxially on the lamina and with narrow basifixed or peltate clathrate paleae ending in a small oblong thin-walled cell on the rhizome, axes and abaxial lamina surface. Sori subglobose, exindusia in the lower part of the lamina, protruding, up to $7.5 \mathrm{~mm}$ in diameter, embedded in the pinna, in a row on either side of the median vein; presence of peeled, pedicelled paraphyses; spherical spores, monolites with a perispore (Figs 3 and 4). Gametophyte mature thallus with a strapshaped posterior and a cordate anterior, midrib thin and wings spreading, rhizoids restricted to the midrib, dehiscence by the collapse of the cap cell. 


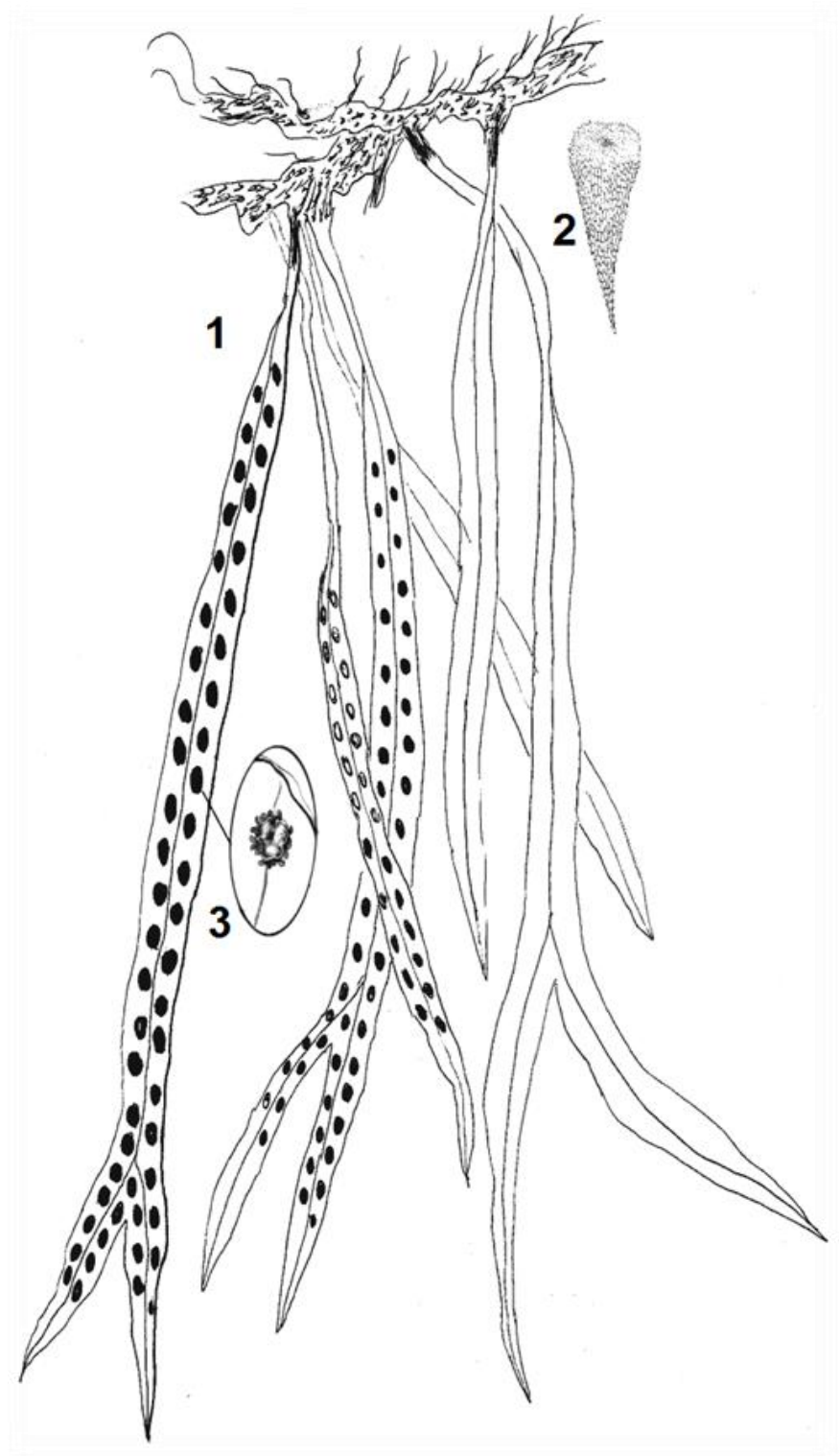

Fig. 4: Lepisorus robbrechtiana: 1, full plant x1/2; 2, scalped $\mathrm{x} 1 / 4$ and 3 , lamina portion in sore (x 6).

Ecology, habitat and distribution: Frequent plant in the middle plateau of Kalehe, Lemera. Also found in the first 2 levels of mountain area of the PNKB. Frequent in the forest at Newtonia buchanani at the edge of streams and secondary forest in open places and sunny areas, especially at roadside sometimes in the shade on tree trunks and on high branches exposed to light. Somewhat uncommon in rainforest, humid and primary forests, but sometimes forming bushy and / or shade on tree trunks and high branches exposed to light. Small individuals of this species were observed at $2352 \mathrm{~m}$ above sea level in the vicinity of mountain crest. Bugulumiza at 2382. Altitude. 1500-2352 m.
Endemic species of the mountain area of the PNKB, INR and PNVi.
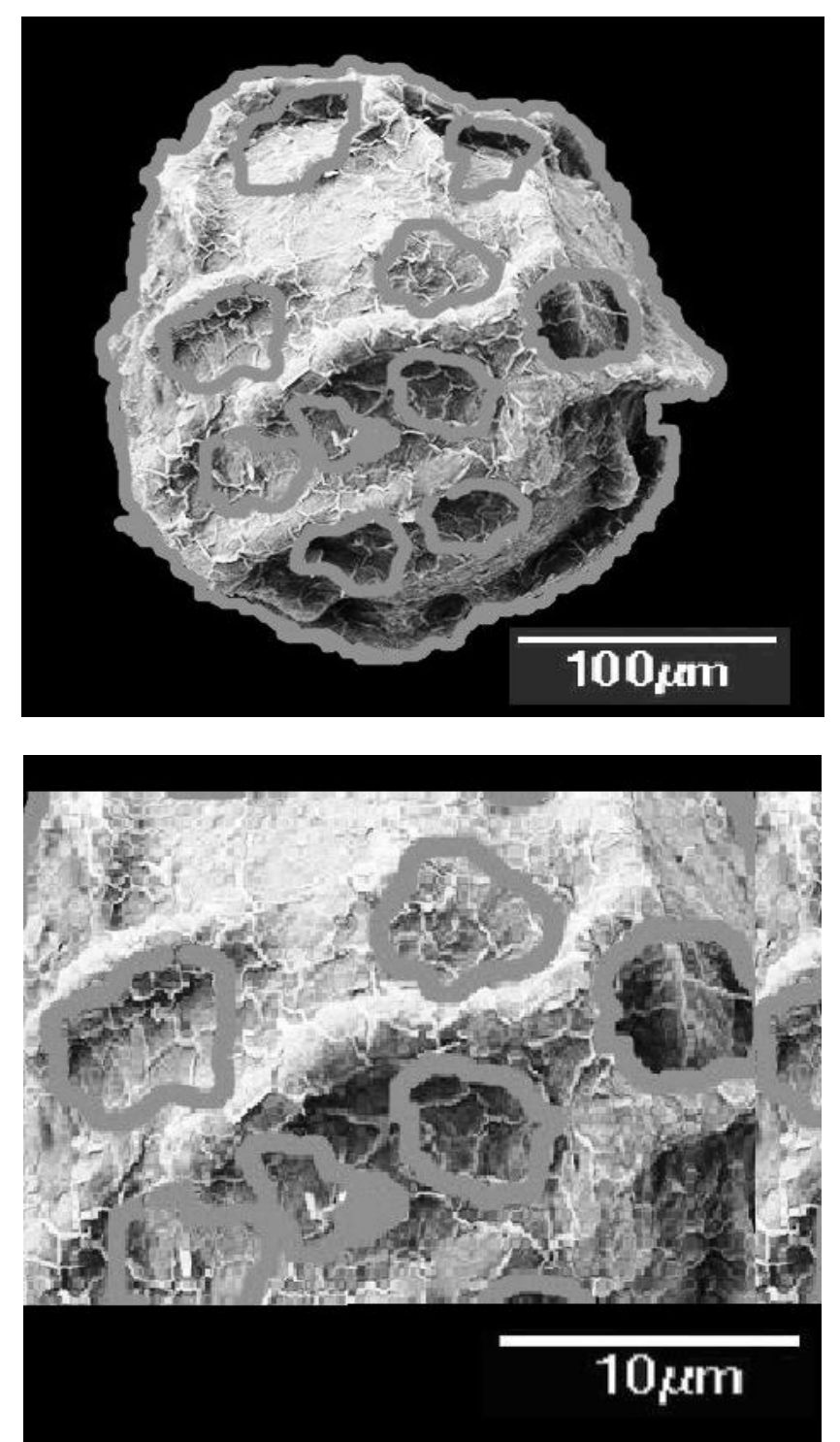

Fig. 5: Lepisorus robbrechtiana, original M.E.B. images showing the overall view of spore in mono-spherical shape $(100 \mu \mathrm{m})$ and magnification $(10 \mu \mathrm{m})$.

Other Specimens examined: Mangambu 738 (BR, LWI): Burhinyi (Itombwe; S323 582, E2845971), 1797 alt.; Mangambu 2206 (BR, LWI): Kilimanyoka (PVi) 1402 alt.; Mangambu 2922 (BR, LWI): North Tshibati (S216812/E2848040), $1745 \mathrm{~m}$ alt.; Mangambu 3365(BR, LWI): Tshibati Nord (S208.997, E2850.616) 1745 m alt. ; Mangambu 3365 (BR, LWI): Tshibati Nord (S208.997, E2850.616) $1745 \mathrm{~m}$ alt.; Mangambu 3672 (BR, LWI): North Tshibati (S215473/ E2848682) $1745 \quad \mathrm{~m}$ alt.; Mangambu 3686 (BR, LWI): North Tshibati 
(S208.997, E2850.616) 1745 m alt.; Mangambu 3676 (BR, LWI): North Tshibati (S215473/ E2848682) 1842 m alt.; Mangambu 3698 (BR, LWI): North Tshibati (702803, 9761515) 1842 alt.; Mangambu 3698(BR, LWI): North Tshibati (S208.997, E2850.616), 1745 m alt.; Mangambu 3912 (BR, LWI): mount Bungulumisa (S17639, E2847269), 2350 m alt.; Mangambu 3913 (BR, LWI): mount Bungulumisa (S17639, E2847269), $2382 \mathrm{~m}$ alt.

Note: Fronds tending towards dimorphism, all assimilating to lamina entirely hairy mixed, scales scattered on the upper face; lamina not identical, some long in forks twice or sometimes thrice, the other short and the protruding sori embedded in the pinna.

\section{Discussion}

The two new species described have affinities with the two other species that exist in eastern DRC. Their connection is manifested in the similarity of the general appearance, yet there are also other numbers of characters and morphological traits which make the difference between them. The tables and identification keys below allow distinguishing them.

Table 1: Overview of the main features to distinguish between Loxogramme ntahobavukiana and Loxogramme abyssinica (Fig. 6).

\begin{tabular}{|c|c|c|}
\hline Features & Loxogramme ntahobavukiana & Loxogramme abyssinica \\
\hline Rhizome & $\begin{array}{l}\text { shortly creeping, not more than } 15 \mathrm{~cm} \text { long; short } \\
\text { phyllopodia, pale or black, lanceolate, acuminate; } \\
\text { narrowly scaled, dense, peeled, pale brown to } \\
\text { brown, acuminate. }\end{array}$ & $\begin{array}{l}\text { long creeping up to } 211 \mathrm{~cm} \text {; long phyllopodia, black, } \\
\text { elliptical; dense scales, black brown, lanceolate, } \\
\text { acuminate. }\end{array}$ \\
\hline Frondes & clump, up to $18.2-46.22 \mathrm{~cm}$ long, oblanceolate base & spaced, $12-40 \mathrm{~cm}$ long with the base, elliptical base \\
\hline stipe & $\begin{array}{l}6.78-18.6 \mathrm{~cm} \text { long, articulated, winged on two } \\
\text { sides up to the rhizome }\end{array}$ & $\begin{array}{l}\text { short (pseudostipe), } 1.7-6.9 \mathrm{~cm} \text { long for long fronds, not } \\
\text { winged }\end{array}$ \\
\hline Lamina & $\begin{array}{l}\text { lanceolate, } 5-36 \times 1-9 \mathrm{~cm} \text { pennatilobed, sometimes } \\
\text { wavy, crenelated when still young, glabrous on the } \\
\text { upper side, scales on the lower side. }\end{array}$ & $\begin{array}{l}\text { elliptical, glabrous, } 7-35 \times 1-2 \mathrm{~cm} \text { lamina, attenuated } \\
\text { shrunken and acute at the top, gradually reduced to the } \\
\text { base in one narrow wing almost to rhizome, entire margin. }\end{array}$ \\
\hline Veins & $\begin{array}{l}\text { obsolete veins only visible when still young, areolas } \\
\text { oblique to the main vein }\end{array}$ & $\begin{array}{l}\text { indistinct, staminated, elevated on the lower side, } \\
\text { anastomosed, visible presence of veins included }\end{array}$ \\
\hline Sori & $\begin{array}{l}\text { mostly linear sori, } 6 \text { to } 11.6 \mathrm{~cm} \text { long, the top of each } \\
\text { sori little or not slightly exceed the base of the } \\
\text { upper sori. }\end{array}$ & $\begin{array}{l}\text { linear, reaching } 3.5 \mathrm{~cm} \text { in length, very oblique to the spine, } \\
\text { the top of each exceeding the base of the upper. }\end{array}$ \\
\hline
\end{tabular}

\section{The two neighboring species can be distinguished as follows}

1. Simple, linear, elliptic, spaced frond, single pinna, elliptic, glabrous, attenuated, narrowed and acute at the top, progressively reduced at the base in a narrow wing almost to the rhizome; not very visible; linear sori, long, very slightly oblique in relation to the central vein; spores ellipsoidal, monolete or trilete, papillate to rugate, $62-70 \mu \mathrm{m}$ long ............................... abyssinica

- Simple fronds, pinnatily-lobed or notched, crenated when still young, near glabrous on the upper side, with hairs and scales on the lower side;lanceolated oblongs and dimidiated at the base, thickenedvein, visible ;linear sores, oblique to the rhachis; spores oblovoidal, monolete .L. ntahobavukiana 

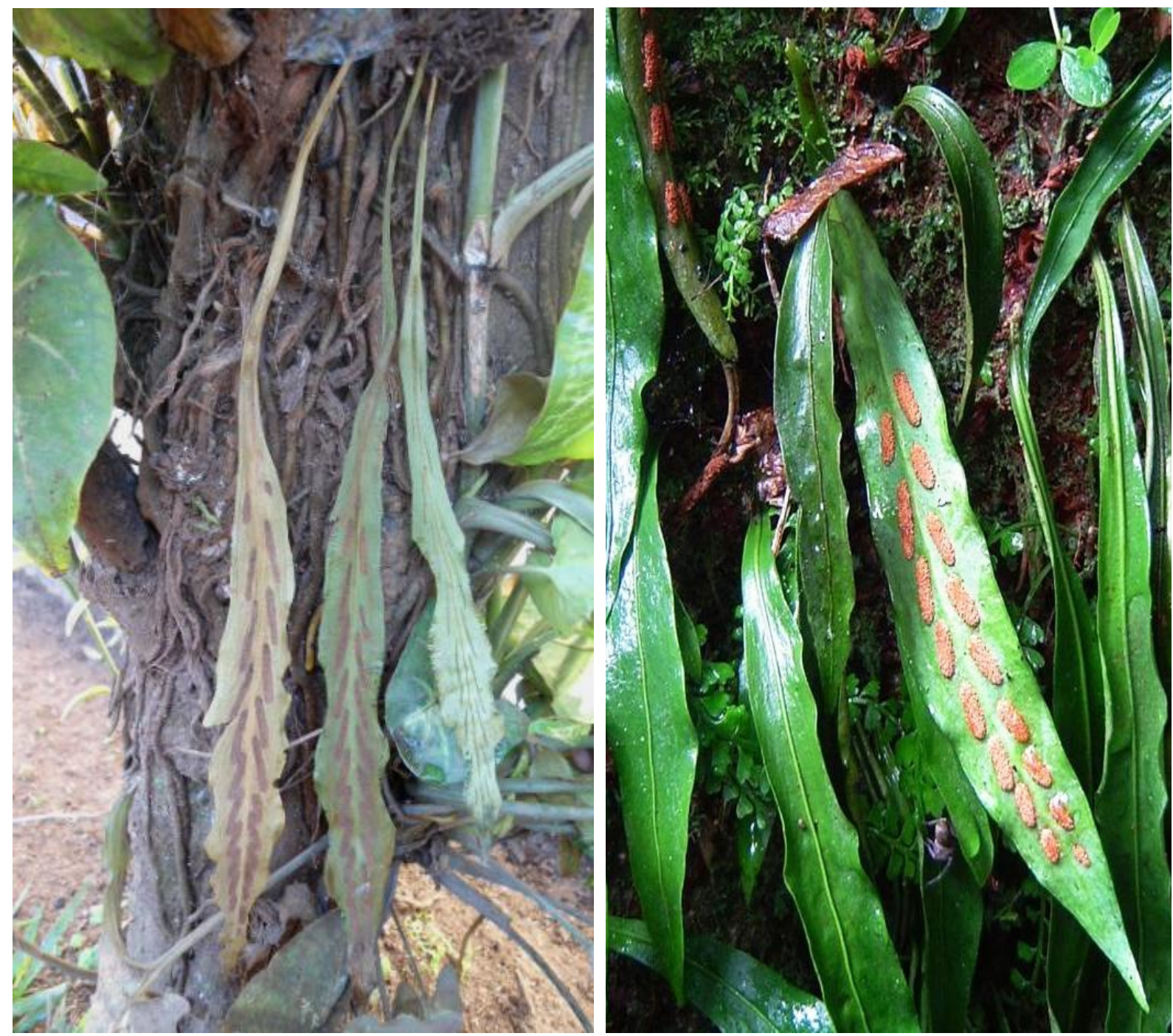

Fig. 6: Loxogramme ntahobavukiana on the left and Loxogramme abyssinica on the right (pictures taken by Mangambu at KBNP).

Table 2. Overview of the main features to distinguish between Lepisorus excavates and Lepisorus robbrechtiana (Fig. 7).

\begin{tabular}{|c|c|c|}
\hline Features & Lepisorus robbrechtiana & Lepisorus excavatus \\
\hline Rhizome & $\begin{array}{l}\text { papery scales, not concolored, more or less peeled, } \\
\text { lanceolate }\end{array}$ & $\begin{array}{l}\text { concolored scales of the rhizome, covered with a white } \\
\text { iridescent substance }\end{array}$ \\
\hline Frondes & two types, more or less with clumps & both equal and similar, monomorphes, spaced, erected \\
\hline Stipe & $\begin{array}{l}\text { hairy, stratified, } 2-10.5 \mathrm{~cm} \text { long, } 1.2-1.5 \mathrm{~mm} \text { in } \\
\text { diameter, scaly, gradually narrowed at the base and } \\
\text { sometimes winged }\end{array}$ & $\begin{array}{l}2-6 \mathrm{~cm} \text { long, } 1 \mathrm{~mm} \text { in diameter, with rare scale in } \\
\text { adulthood }\end{array}$ \\
\hline lamina & $\begin{array}{l}\text { not identical and unequal, one is long and lobed ( } 30- \\
41 \mathrm{~cm} \text { ) dichotomous at the top (once to twice in } \\
\text { forks), the others are wholly small }\end{array}$ & $\begin{array}{l}\text { Identical lamina identical, } 33(-47) \mathrm{cm} \text { long and 0.6-2.7 (- } \\
\text { 3) } \mathrm{cm} \text { wide, simple with rare scales in the adulthood }\end{array}$ \\
\hline vein & $\begin{array}{l}\text { dichotomous at the top for lamina in forks and not } \\
\text { dichotomous for simple and short lamina }\end{array}$ & Simple, branched for all lamina \\
\hline Sori & $\begin{array}{l}\text { on the upper } 4 / 5 \text { of the lamina, globose, } 4.3-7.76 \mathrm{~mm} \\
\text { in diameter }\end{array}$ & $\begin{array}{l}\text { circular, large, medial, in a single row parallel, on the } \\
\text { upper } 2 / 3 \text { of the lamina, round, } 2.5-5 \mathrm{~mm} \text { in diameter, } \\
\text { more rarely slightly elliptic }\end{array}$ \\
\hline
\end{tabular}




\section{The key feature distinguishing the two neighboring species is this}

1. Fronds all equal and similar, tender, spaced, erect; Short stipe; similar lamina; simple with rare scales at adulthood, pinna simple, hypostomatic venation anastomosing, Sori circular, large, medial, in a single row parallel, circular, large, medial, in a single row parallel, on the upper $2 / 3$ of the lamina, spores ellipsoidal, monolete.

.L. excavates

- Fronds in unequal, ascending sizes; not similar pinna, some long and lobed $(30-61 \mathrm{~cm})$ with dichotomous main vein, others short (8-16) wholly small, wholly single gradually narrowed to single ve; Sori subglobose, only in the upper part of the lamina (2/3), round with elliptic.......................................................................... robbrechtiana
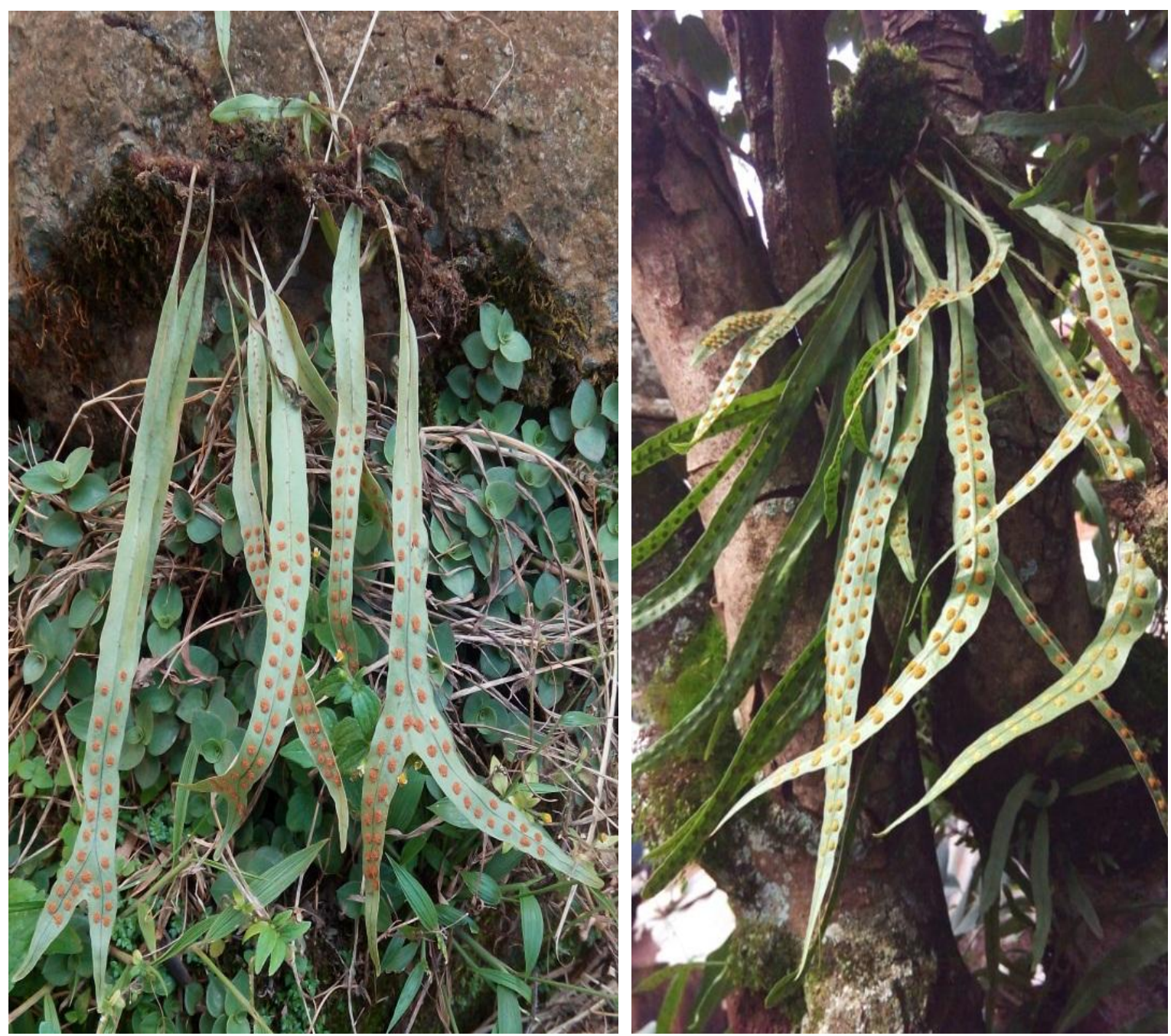

Fig. 7: Lepisorus robbrechtiana on the left and Lepisorus excavatus on the right (photos taken by Mangambu in Kahuzi-Biega National Park).

\section{Taxonomic considerations}

Prior to this study, the importance of this region in Pteridophyta is confirmed by the inventory conducted by Pichi-Sermolli (1983 and 1985). For example, these inventories carried out in 1972 in the Kivu region (DRC) and the mountainous areas of Rwanda and Burundi resulted in the discovery of 9 new species of ferns and allies ferns (Aleuritopteris vandervekenii (RDC), Pteris auquieri (Rwanda, Burundi), P. microlepis (Rwanda) Vandenboschia inopinata (DRC, Rwanda, Burundi and various countries of tropical Africa, Madagascar and 
Mascareignes) Blotiella bouxiniana(Rwanda Burundi), Blotiella trichosora (Burundi), Maclethelypteris rammelooi (Rwanda), Metathelypteris vandervekenii (Rwanda), and Christella burundensis (Burundi). The same inventories led Bizzarri (1981) to describe two new species: Selaginella vanderystii"encountered in the Congo Basin in the DRC", and Selaginella kivuensis in the Kivu Mountains in eastern DRC).

Specimens from Kivu in the DRC and the Rwanda escarpment have led Lawalree (1990) to discover two new species of the Tectariaceae family (Arthropteris anniana and Arthropteris antungupffertiae). Apart from these intense studies, other authors have described species whose material comes from this region. For example, the species: Lycopodium carolinum (endemic to Mount Kahuzi in the PNKB), Asplenium ruthuruense endemic to the escarpments of the Ruthuru area north of Mount Nyamulagira and other species such as Asplenium lambinonii and Selaginella auquieri.

Mangambu et al. (2013) reported the presence of 22 new species for the Pteridological flora of the DRC, discovered in the mountain forest of KBNP, the majority of which were considered by Pichi -Sermolli (1983) as endemic to Rwanda or Burundi, for example, Pteris auquieri, Metathelypteris vandervekenii, Mangambu et al. (2016) in their molecular investigations of the genus Asplenium of the mountainous region of the Kivu, described a new Asplenium kivuensis.

\section{Paleoenvironmental and biogeographical considerations}

Some authors (Barthlott et al., 1996; Plumptre et al., 2009) consider that the mountain regions are rich in plant diversity but with a systematic that is always fragmentary and difficult due to multiple changes in plants at different altitudes (Kapos et al., 2000). They are areas rich in species of plants than the plains and host the richest communities of plants on the planet (White 1993; Barthlott et al., 1996). At present, the two species described are all endemic to the Kivu-Ruwenzori mountain range in eastern DRC, that is, their chorological boundaries are in these three main conservation reversals of Eastern DRC (KBNP, INR and ViNP).

Fieldwork on the DRC pteridology has shown that the majority of these species are located in the mountains of the Kivu-Ruwenzori system (Bizzarri, 1981 and 1983; Pichi-Sermolli, 1983; Aldasoro et al., 2004). The reason for this diversity can be accounted for by the effects of scenarios of paleoenvironmental variability (Meadows and Linder 1993; Marchant and Hooghiemstra, 2004; Runge, 2007). According to these authors, the Congolese mountain system has a continually changing vegetation cover in response to macroclimatic and microclimatic variations due to the climatic stability of past geological times (Fjeldsä and Lovett, 1997; Maley, 1980 and 1990).

That has allowed climatic conditions favorable to vascular plants, which can retain spores and pollen grains capable of germinating after several years (Runge, 2007; Guillaumet, 2009). The same theory asserts that there is a migration of species at lower altitudes to high altitude after the latest glaciation (Roche, 1991). Furthermore, several studies have highlighted the importance of Pleistocene and Holocene climatic fluctuations to explain the current distribution of plants in this Congolese mountain system (Plumptre et al., 2008).

The territory is marked, as regards the historical chronology of the climatic events, by the alternation of the cold and warm periods. These cyclic climatic variations have had a major influence on plant diversity and on the evolution of vegetation cover in eastern DRC and Rwanda (Tchouto et al., 2008). In the eastern area of the Kivu-Tanganyika region, during the period between 23000 and 3000 years BP, the vegetation reflects a colder climate than the current one; (Faden, 1994; Mayr and O'hara, 1986; Maley, 1987; Roche, 1991; Roche and Ntaganda, 1999; Runge, 2007). We confirm that this region of Kivu, like other African mountainous regions, is also rich in ferns and allies ferns. The two species of affinity with the two species described have a wide distribution (Figs. 8 and 9).

Loxogramme abyssinica, is a multi-regional species of Afro-Malagasy origin distributed in mountains or hilltops of medium altitudes (Autrey et al, 2008; Roux, 2009) of seven mountain systems of White (1978 and 1983) in southern and eastern Africa, Madagascar, Comoros, Mauritius and Reunion. While Lepisorus excavatus, a mountain-dwelling Afro-Malagasy species (Fig. 7), is distributed only in mountains and medium altitude formations (Autrey et al., 2008; Roux, 2009) in the Kivu-Ruwenzori system countries (Burundi, Rwanda and Uganda), Ethiopian system (Ethiopia), ImatongsUsambara system (Kenya), Madagascar, UluguruMlanje (Tanzania) 


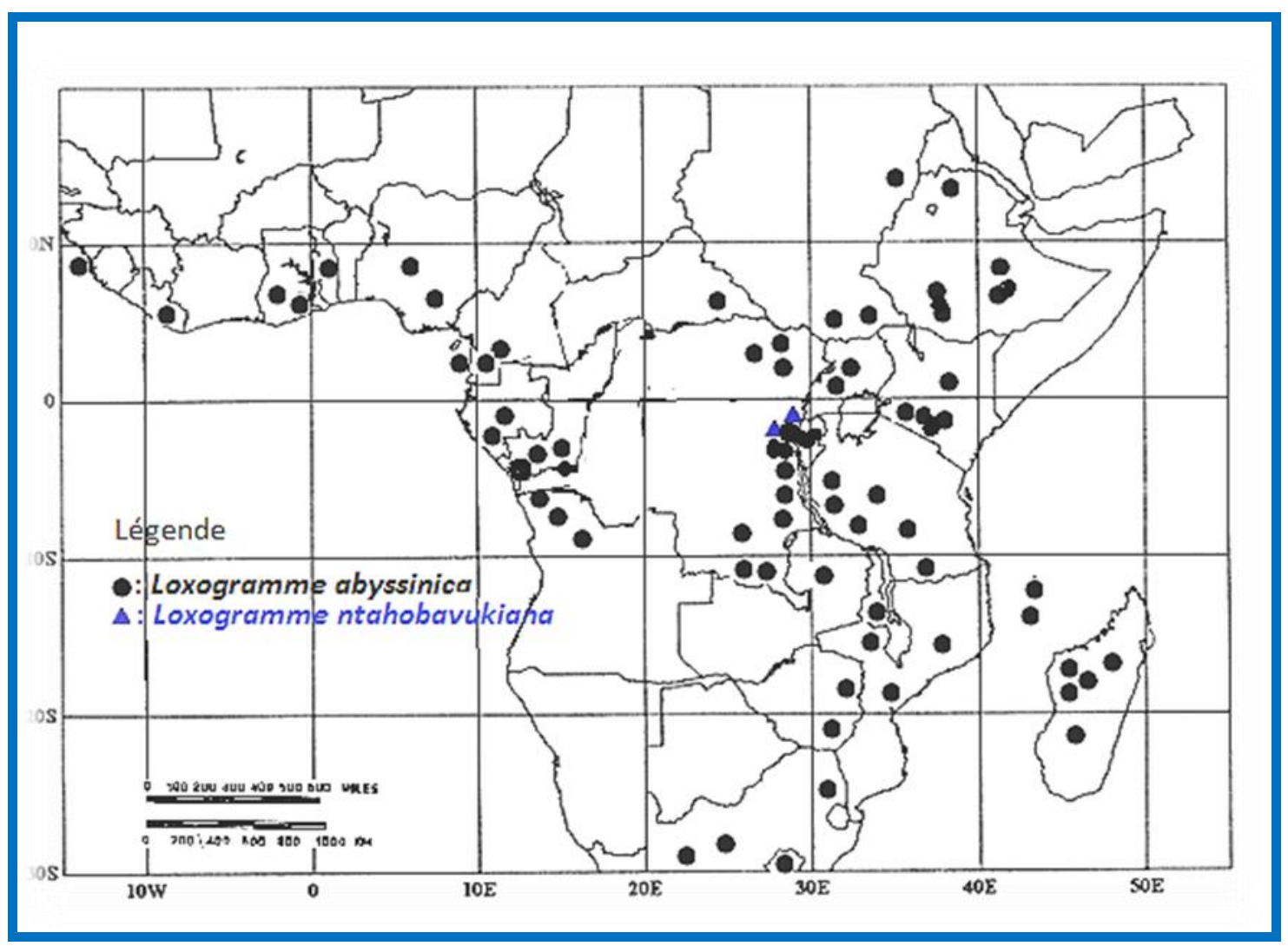

Fig. 8: Distribution maps: Loxogramme abyssinica (in black points) and L. ntahovabukiana (in blue triangle).

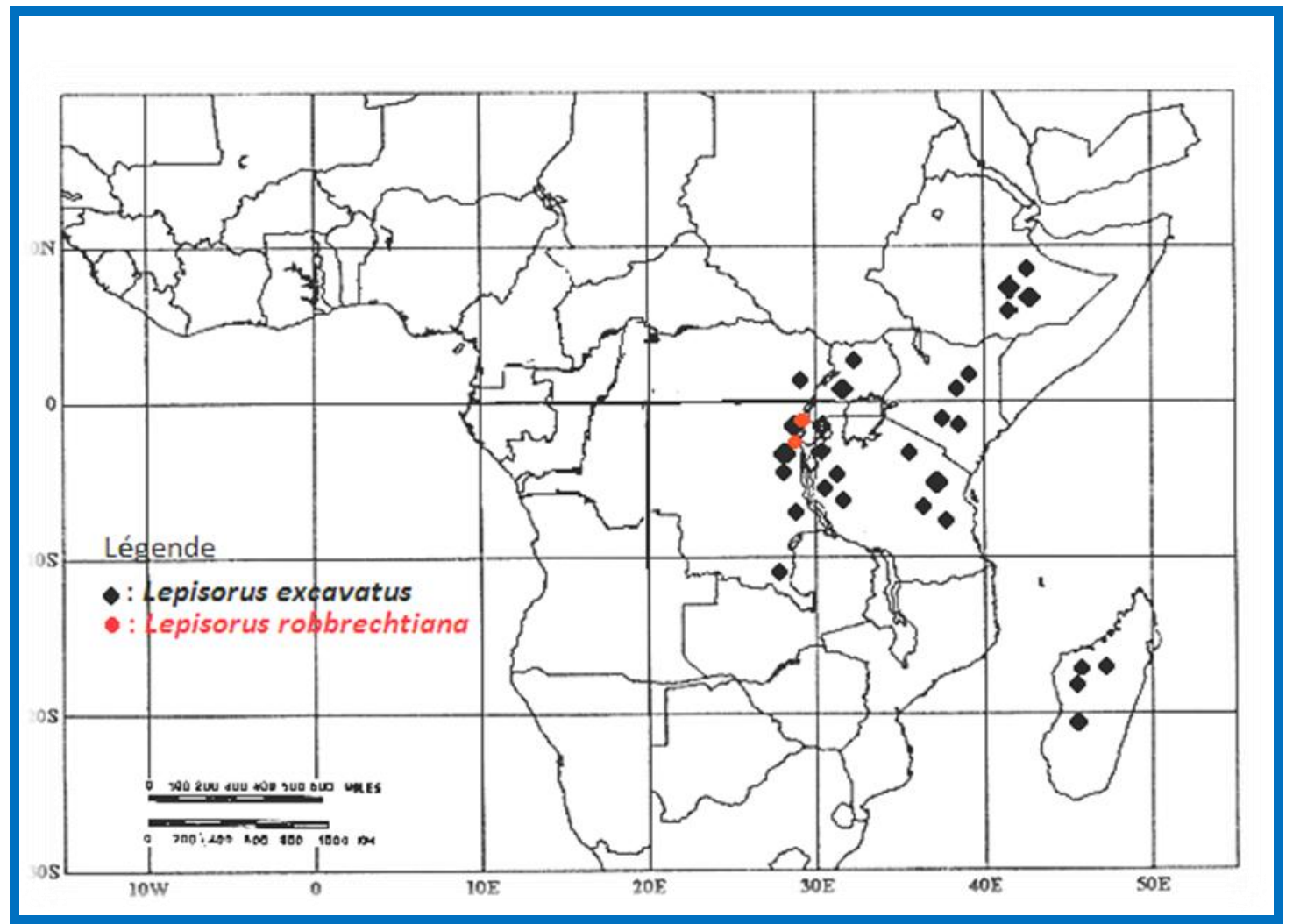

Fig.9: Distribution maps: Lepisorus excavates (in black points) and L. robbrechtiana (in red rhombus). 


\section{Conclusion}

The field studies carried out have just shown that knowledge of the flora of the DRC remains fragmentary despite more than a century of multiple explorations and plants gathering achieved. Thus, we suggest that local researchers be supported financially, in order to realize multiple crops of plants in general and of the ferns and allies ferns in particular.

We believe that the discovery we have just made shows that the bioclimatic conditions in the mountain ranges of eastern DRC are conducive to the development and diversity of the Pteridophytes following the habitats that allow their implantation and development to disseminations of the diaspores. Radiation, atmospheric humidity, especially precipitation and mesothermal shade species favor their development and abundance. This is why we have a high rate of epiphytic plants in comparison to terrestrial species.

\section{Conflict of interest statement}

Authors declare that they have no conflict of interest.

\section{Acknowledgement}

This work was carried out thanks to the material and financial support granted by the Belgian Technical Cooperation (BTC). We would also like to thank UNESCO, through the Flemish government (Belgium) for their contribution to the fieldwork and trips to the herbaria (BR, LWI, ULB, GL, GENT, WAGENINGEN, KEW ...) for the checking and observation of the reference material. Thanks also to the anonymous peerreviewers of this paper.

\section{References}

Aldasoro, J., Cabezas, F., Aedo, C., 2004. Diversity and distribution of ferns in sub-Saharan Africa, Madagascar and some islands of the South Atlantic. J. Biogeo. 31, 1579-1604.

Autrey, J., Bosser, J., Ferguson, I., 2008. Flore des Mascareignes-Ptéridophytes- Psilotacées à Marsiléacées. Inst. Rech. t Dévelop. pp.1-462.

Barthlott, W., Porembski, S., Szarzynski, J., Mund, J., 1996. Phytogeography andvegetation of tropical inselbergs. In: Phytogéographie Tropicale Réalités et Perspectives. Phytogéographie Tropicale (Eds. : Guillaumet, J., Belin, M.). Puig: Col. Intern. Hom.
Prof. Schnell, Paris. pp.15-24.

Bizzarri, M.P., 1981. Two new species of Selaginella (Selaginellaceae) from Zaire. Bull. Jard. Bot. Nat. Belg. 51(1/2), 219-224.

Bizzarri, M.P., 1983. Two new species of Selaginella (Selaginellaceae) from Zaire. Jard. Bot. Nat. Belg. 53(1/2), 171-176.

Cribb, P., Fischer, E., Killmann, D., 2010. A revision of Gastrodia (Orchidaceae, Epidendroideae, Gastrodieae) in Tropical Africa. Kew Bull. 65, 315321.

Crouch, N., Klopper, R., Burrows, J., Burrows, S., 2011. Ferns of Southern Africa, a comprehensive guide. Struik Nat. 1-532.

Detchuvi, J.-B., Fischer, E., 2006. A new species of Aframomum (Zingiberaceae) from Nyungwe National Park / Rwanda. Syst. Geogr. Plant.76, 241245.

Faden, R.B., 1994. Upland Kenya Wild Flowers, East African Natural. $2^{\text {nd }}$ Edn. East Afr. Nat. Hist. Soc. Nairobi-Kenya. pp.1-374.

Fischer, E., Detchuvi, J.-B., Ntaganda, C., 2003. A new species of Impatiens (Balsaminaceae) from Nyungwe Forest, Rwanda. Syst. Geogr. Plant. 73,91-95.

Fjeldsä, J., Lovett, J.C., 1997. Geographical patterns of old and young species in African forest biota: The significance of specific Montane areas as evolutionary centres. Biodiv. Conserv. 6, 325-346.

Guillaumet, J-L., 2009. La végétation des montagnes du Rift. In: Hirsch, B. (dir.), Roussel Bernard (dir.), Verdeaux François (collab.), Fauvelle-Aymar, F.X. (collab.), Coppens, Y. (préf.) Le Rift est-africain: une singularité plurielle. Marseille (FRA); Paris: IRD; MNHN. pp.195-204.

Hu, X-Y., Zhai, J., Wang, F-G., Xu, X.L., 2010. Simple treatment to investigate spore ornamentation of ferns for SEM observation from herbarium specimens. Pak. J. Bot. 42(4), 2335-2338.

Kapos, V., Rhind, J., Edwards, M., Price, M., Ravilious, C., 2000. Developing a map of the world's mountain forests. In: Forests in Sustainable Mountain Development: A State-of-Knowledge Report for 2000 (Eds.: Price, M.F., Butt, N.). Wallingford, IUFRO, UK.

Lachenaud, O., Jongkind, C., 2010. Three new or littleknown Chassalia (Rubiaceae) species from West and Central Africa. Nordic J. Bot. 28, 13-20.

Lawalrée, A., 1990. Deux espèces Africaines nouvelles d'Arthropteris (Nephrolepidaceae). Jard. Bot. Nat. Belg. 60, 317-324. 
Lawalrée, A., 1991. Arthropteris charletiana (Nephrolepidaceae), espèce nouvelle du Kivu (Zaïre). Jard. Bot. Nat. Belg. 61, 356-357.

Linder, H., 2001. Plant diversity and endemism in subSaharan tropical Africa. J. Biog. 28, 169-182.

Maley J., 1990. Synthèse sur le domaine forestier africain au Quaternarie recent. Paysage Quaternaries de l'Afrique Centrale Atlantique (Eds.: Lanfranchi, R., Scwartz, D.). ORSTOM, Paris. pp.383-389.

Maley, J., 1980. Les changements climatiques de la fin du Tertiaire en Afrique: Leusconsequence sur l'aparition du Sahara et de sa vegetation. The Sahara and the Nile (Eds.: Williams, M.A., Faure, H.). A.A. Balkema, Rotterdam. pp.63-86.

Maley, J., 1987. Fragmentation de la forêt dense humide africaine et extension des biotopes montagnards au Quaternaire récent: nouvelles données polliniques et chronologiques. Implications paléo climatiques et biogéographiques. Palaeoeco. Afr. 18, 307-334.

Mangambu, M., Aluma, K., van Diggelen, R., RugendaBanga, R., Mushangalusa, K., Chibembe, S., Ntahobavuka, H., Nishuli, B., Robbrecht, E., 2015. Etudes ethnobotanique et ethnolinguistique des ressources forestières ligneuses utilisées par la population du couloir écologique du parc national de Kahuzi-Biega (R D. Congo). Eur. Sc. J. 11(15), 135162.

Mangambu, M., 2013. Taxonomie, biogéographie et écologie des Ptéridophytes de l'écosystème forestier des montagnes du Parc National de Kahuzi-Biega à l'Est de la R.D. Congo. Thèse de doctorat, Université d'Anvers/Belgique.

Mangambu, M., Janssen, S, Robbrecht, E., Janssen, T., Ntahobavuka, H., van Ruurd, D., 2016. A Molecular Investigation of Asplenium: Asplenium kivuensis nov. ${ }^{*}$ - A New Species from Kivu (Democratic Republic of Congo). Int. J. Curr. Res. Biosci. Plant Biol. 3(2), 27-37.

Mangambu, M., Robbrecht, E., Janssen, T., Misakabu, M.F., Kaleme, K.P., Ntahobavuka, H.H, van Diggelen, R., 2014. Analysis of the Congolese distribution of Ferns and Allies mountainous of Kahuzi Biega National Park (Democratic Republic of the Congo): Contribution to the conservation of actual protected areas in the Park. Int. J. Biol. Sci. 12(6), 1-23.

Mangambu, M., Van Diggelen R., Mwanga Mwanga, JC, Ntahobavuka, H., Robbrecht, E., 2013. Espèces nouvellement signalées pour la flore ptéridologique de la République Démocratique du Congo. Int. J. Biol. Chem. Sci. 7(1), 107-124.
Mangambu, M., van Diggelen, R., Mwanga Mwanga, JC., Ntahobavuka, H., Robbrecht, E., 2012. Checklist des Ptéridophytesde l'écosystème forestier des montagnes du Parc National de Kahuzi-Biega à l'Est de la R.D. Congo. Cah. Cent. Rech. Univers. Kiv. 42(2/2), 363-374.

Mangambu, M., 2016. Diversité, Biogéographie et Ecologie des Ptéridophytes en Afrique Centrale : Cas de massif montagneux du Parc National de Kahuzi-Biega à l'Est de la RD. Congo. Ed. Univer. Europ., Berlin.

Marchant, R., Hooghiemstra, H., 2004. Rapid environmental change in Africa and South American tropics around 4000 years before present: A review. Eart. Sci. Rev. 66, 217-260.

Mayr, E., O'Hara, R., 1986. The biogeographic evidence supporting the pleistocene forest refuge hypothesis. Evol. 49, 55-67.

Meadows, E., Linder, H., 1993. A Palaeoecological Perspective on the Origin of Afromontane Grasslands. J. Biog. 20(4), 345-355.

Pichi-Sermolli, R., 1985. A contribution to the knowledge of the Pteridophyta of Rwanda, Burundi, and Kivu (Zaire) II. Bull. Jard. Bot. Nat. Belg. 55, 123-206.

Pichi-Sermolli, R., 1983. A contribution to the knowledge of the Pteridophyta of Rwanda, Burundi, and Kivu (Zaire) I. Bull. Jard. Bot. Nat. Belg. 53, 177-284.

Plumptre, A., Eilu, G., Ewango, C., Ssegawa, P., Nkuutu, D., Gereau, R., Beentje, H., Poulsen, A. D., Fischer, E., Goyder, D., Pearce, T., Hafashimana, D., 2007. The biodiversity of the Albertine Rift. Biol. Conserv. 134, 178-194.

Plumptre, A., Amsini, F., Kujirakwinja, D., Hart, J., Nyembo, B., Vyahavwa, C., Bujo, F., Masanga, A., Matunguru, J., Mwinyihali, R., Tshombe, R., 2009. Itombwe Massif conservation Project; Delimitation and zoning of the Itombwe natural Reserve for protection for protection ofgreat apes. Unpublished Report to US Fish and Wildlife Service.

Plumptre, A., Kujirakwinja, D., Matanguru, J., Kahundo, C., Kaleme, P., Marks, B., Huhndorf, M., 2008. Inventaires biologiques des régions de Misotshi-Kabogo (Mont et Marungu à l'est de la en RDC. Albertine Rilf Technical Reports. Unpublished report, Wildlife Conservation Society. pp.1-114.

Roche, E., 1991. Evolution des paléoenvironnements en Afrique centrale et orientale au Pléistocène supérieur et à l'Holocène. Influences climatiques et 
anthropiques. Bull. Soc. Géogr. Lièg. 27, 187-208.

Roche, E., Ntaganda, C., 1999. Analyse palynologique de la séquence sédimentaire Kiguhu II (Région des Birunga, Rwanda). Evolution du paléo environnement et du paléoclimat dans le domaine Afromontagnard du Rwanda au cours de l'Holocène. Geo-Eco-Trop. 22, 71-82.

Roux, J.P., 2001. An enumeration of the Pteridophyta of Angola, Botswana, Lesotho, Malawi, Mozambique, Namibia, South Africa (including the Marion Island group), Swaziland, Zambia and Zimbabwe. Compton Herbarium, National Botanical Institute, Southern African Botanical Diversity. Net. Rep. $\mathbf{N}^{\mathrm{o}}$ $13,1-235$.

Roux, J.P., 2009. Synopsis of the Lycodiopyta and Pteridophyta of Africa, Madagascar and neighbouring islands. Strelitzia 23. S. Afr. Nat. Biod. Inst., Pretoria.

Runge, J., 2007. Des déserts et des forêts, histoire du paysage et du climat de l'Afrique Centrale au Quaternaire Supérieur. Geo-Eco-Trop. 31, 1-18.
Tchouto, M., de Wilde, J., de Boer,W., van der Maesen, L., Cleef, A., 2008. Bio-indicator species and Central African rain forest refuges: a case study from the rain forest in Cameroon. Syst. Biodiv. 7(1), 21-31.

White, F., 1983. The Vegetation of Africa. A descriptive Memoire to Accompany the UNESCO/AETFAT Vegetation Map of Africa. UNESCO, Paris, UNESCO/ AETFAT.

White, F., 1986. La végétation de l'Afrique. Mémoire accompagnant la carte de végétation de l'Afrique UNESCO/AETFAT/UNSO. ORSTOM et UNESCO. Paris, collection Rech. Ress. Nat. 20, 1384.

White, F., 1993. The AETFAT chorological classification of Africa: history, methods and applications. Bull. Jard. Bot. Nat. Belg. 62, 225-281.

White, F., 1978. The Afromontane region. In: Biogeography and Ecology of Southern Africa (Ed.: Werger, M.J.A.). Junk Publishers, The Hague 1. pp.463-513.

\section{How to cite this article:}

Mangambu, M., Van Diggelen, R., 2017. Two new species of Loxogramme and Lepisorus (Polypodiaceae): Endemic ferns from Kivu-Ruwenzori Mountain System (Eastern D.R. Congo, Albertine Rift). Int. J. Curr. Res. Biosci. Plant Biol. 4(4), 61-74. doi: https://doi.org/10.20546/ijcrbp.2017.404.010 